\title{
Literatura y crítica literaria ${ }^{1}$
}

\author{
ROgER BOZZETTO*
}

Resumen:

Este trabajo desarrolla una reflexión sobre los distintos lenguajes y códigos con que es representable la realidad. Es también un análisis de cómo, según las épocas, diversas mitologías se imponen; las ideologías que ellas recubren activan figuras, imágenes, incluso conceptos, y presentan su concepción de la realidad como reflejo de la naturaleza de las cosas y cómo lo mismo ocurre en la literatura, donde diversos géneros se imponen y vuelven caducas formas autóctonas, ocultando su nacimiento y desarrollo.

Es también una breve historia de las distintas caras de los discursos que pretenden representar la irrealidad o una realidad alternativa, de los mitos a lo real maravilloso. Historia ilustrada con ejemplos de diferentes variantes de lo maravilloso, con la historia del nacimiento de un género, el fantástico, y de sus variantes, finalizando con lo real maravilloso. Historia que permite recordar que toda cultura está inmersa en un universo simbólico que la constituye y que ella utiliza a su manera. Es cierto que se apoya en la presencia subterránea pero pregnante de mitos, y de referencias, aun cuando sean sólo metafóricas, a lo sobrenatural, pero los mitos ya no son los grandes relatos que sostienen al mundo, sino apenas una parte modesta de nuestros signos y nuestras explicaciones y tras la "occidentalización" del mundo, los textos se sitúan en la periferia de esa ideología excluyente y reflejan otras formas de convivencia entre la explicación de lo real y lo fantástico.

${ }^{1}$ Traducción del francés de José Miguel Sardiñas. Este trabajo fue publicado en francés y en una versión ligeramente diferente en Magdelaine, Marimoutou y Terramorsi.

*Université d'Aix-en-Provence. 
Palabras clave:

Orígenes de lo fantástico, discurso mítico, lo maravilloso, real maravilloso, mitología y literatura.

Cada pueblo, cada cultura, cada lengua inventa sus versiones de la realidad y se nutre del imaginario, abrevando en "el Océano de los cuentos" del que habla la literatura india. Según las épocas, diversas mitologías se imponen; las ideologías que ellas recubren activan figuras, imágenes, incluso conceptos, y presentan su concepción de la realidad como reflejo de la naturaleza de las cosas. Lo mismo sucede en la literatura, donde diversos géneros se imponen y vuelven caducas formas autóctonas, ocultando su nacimiento y desarrollo. Pero estas mismas formas acaban por ser susceptibles de obsolescencia, pues la cultura evoluciona, y las culturas minoritarias se aprovechan de ello para florecer, puesto que son mejores entonces para incluso explicar la realidad. Es por lo que es inútil buscar modelos de representación válidos para todas las culturas y todas las épocas. Es por lo que tampoco puede haber universales críticos aplicables a todos los textos y válidos para todas las creaciones culturales. Cada instrumento crítico es producto de una historia singular y se basa en el conocimiento de un corpus limitado de textos precisos. Utilizar esos instrumentos genéricos como si fueran objetos del mundo y no el producto de una historia conduce a absurdos -cuando no a extravíos del pensamiento... en el mejor de los casos.

Trataremos de ilustrar estas afirmaciones por medio del ejemplo de las variantes de lo maravilloso, con la historia del nacimiento de las variantes de lo fantástico y tomando en cuenta lo real maravilloso. ${ }^{2}$

${ }^{2}$ En español en el original, aquí y a lo largo del texto; en adelante, las palabras o frases no traducidas al español y puestas en cursivas se conservan en las lenguas en que aparecen en el original, y no se traducen por ser de uso frecuente también en el lenguaje de la crítica escrita en español [N. del T.]. 


\section{Presencia de las variantes de lo maravilloso}

\section{El espacio de los mitos}

Lo que caracteriza a la especie en vías de hominización es sin duda la conciencia de lo ineluctable de la muerte. Es lo que constituye el primer "impensable" de la humanidad naciente. Ésta inventa entonces, para paliar los efectos del "peur cosmique" ("miedo cósmico") (Lovecraf 9) ${ }^{3}$ y de sus consecuencias, ritos funerarios, y mitos que se supone que den un sentido a ese impensable. Se recurre a lo imaginario porque lo real de la muerte no puede simbolizarse. El nacimiento de los mitos está ligado al de los ritos, y esto desde las más antiguas religiones conocidas en Occidente, y originarias del Medio Oriente (Bottéro). Esta imposibilidad humana de pensar lo real de la muerte, como lo que se deriva de ella -el sentido de la vida- tiene como consecuencia recurrir a figuraciones, tanto pictóricas (las cuevas lo testimonian) como escultóricas (las Venus) o narrativas -los mitos. El mito es, de entrada, un relato oral que plantea por el desvío de lo imaginario un conjunto de representaciones y de actos. Los mitos dotan a una cultura de una respuesta a lo que ella percibe como un misterio, a saber, su origen, su lugar en el universo y el sentido que eso impone para la comunidad y su conjunto y para cada uno (VV AA, "Mythes et mythologie"). Es el caso, en la cultura judeocristiana, de los relatos del Génesis y del de la torre de Babel. Según André Jolles, el mito se propone como una pregunta formulada por el hombre al universo y como la respuesta del universo a esa pregunta (58). A la pregunta "¿quién creó el lenguaje?”, la Biblia responde: Adán. ¿Por qué las lenguas son tan diversas? La respuesta es dada por el mito de la torre de Babel. El mito confiere autoridad y da seguridad puesto que se supone que dé a su manera la respuesta de la Sobrenaturaleza, que aparece se-

3 “La plus vieille, la plus forte émotion ressentie par l'être humain c'est la peur. Et la forme la plus puissante découlant de cette peur c'est la peur de l'Inconnu" ("La más antigua, la más fuerte emoción sentida por el ser humano es el miedo. Y la forma más poderosa derivada del miedo es el miedo a lo Desconocido") (Lovecraft 9). 
gún las culturas en diversas formas: animales, monstruosas o humanas. Desde el punto de vista formal, el mito es, de entrada, según Levi-Strauss, un relato oral particular donde "la succession des événements" no está "subordonnée à aucune règle de logique ou de continuité", pues "tout peut arriver dans un mythe"4 (229-232). Es, según Teón de Alejandría, "un discours mensonger exprimant la vérité en image" (Progymnasta III. En Demeretz 33), con su lógica y su eficacia propia, que Levi-Strauss calificó, admirándola, como "pensamiento salvaje".

Los mitos se combinan entre sí y acaban por formar un conjunto de ecos y relatos que fundan una mitología, con lo cual proponen una aparente racionalidad. De esta forma encontramos, según las culturas, mitologías diversas, que persiguen el mismo propósito, independientemente de que se trate de la india, la nórdica, la grecorromana, la judeocristiana, la persa preislámica, la china o la precolombina, o de que provenga de los aborígenes australianos o sea originaria de las islas Mascareignes o de alguna zona del África. Los ritos, verdaderos sistemas de saberes y creencias, sirven después de materia a relatos que presentan a hombres y dioses en el mismo espacio fictivo, constituyen un "género" que se ha calificado de épico. ${ }^{6}$ Es el caso de las epopeyas, tanto la de Gilgamesh como la Odisea o el Mahabharata. ${ }^{7}$ Luego subtienden de manera más sutil todo anclaje novelesco -en ocasiones visible en Frankenstein or the Modern Prometheus, y en ocasiones subyacente en numerosos textos de ficción.

4 "La sucesión de los acontecimientos"; "subordinada a ninguna regla de lógica o de continuidad"; "todo puede suceder en un mito."

5 "Un discurso mentiroso que expresa la verdad como imagen."

${ }^{6}$ Sin olvidar su representación teatral como parte de "misterios" o de tragedias.

7 "Lo maravilloso en la literatura ha de relacionarse con el asombro en la ciencia, según Aristóteles (ésta nace del asombro). Éste no es un artificio; es un medio de interrogar tanto a la realidad, a lo verosímil, como a la creencia" (Schaufelberger y Vincent 93-96). 


\section{Los maravillosos de los cuentos}

Paralelamente a estos grandes relatos, el mundo de lo imaginario ha visto florecer, a lo largo del tiempo, una multitud de relatos cortos que, como las epopeyas, presentan porosidad en la frontera entre los mundos sobrenaturales y el de los humanos. Son cuentos que a veces proponen temas cómicos -los cuentos humorísticos-, o explotan temas tenebrosos -los cuentos de miedo-, o incluso cuentos más complejos, los llamados "feéricos" o "maravillosos". Estos cuentos están presentes en el imaginario de todas las culturas, con elementos en cada caso diferentes, pero con desarrollos a menudo semejantes: constituyen a su manera el "género" cuento.

Así los cuentos chinos. La frontera entre el mundo de los vivos y el de los muertos es permeable: unos muertos pueden irse de banquete con un letrado que vaga de noche en un cementerio; un juez muerto puede continuar celebrando sesión en el más allá; puede cambiar la cabeza de una mujer fea por la de una belleza para dar gusto a un vivo que es amigo suyo; unos resucitados pueden unirse a un hombre ("Teng Mu ivre visite le parc des Paysages Assemblés"). La frontera con la animalidad es también porosa: encontramos hombres y mujeres zorros, que pueden unirse a letrados o a campesinos. Un espíritu de abeja puede transformarse en muchacha, exactamente como los espíritus de las flores pueden cuidar a un jardinero ("La jeune fille en robe verte"). Lo mismo sucede con la frontera entre los dioses y los hombres, lo que engendra historias de amor entre hombres y doncellas dragones ("La fille du roi dragon"). El mundo de los distintos maravillosos, impregnado de Sobrenaturaleza, es, pues, más vasto que el que presentan los cuentos occidentales de Grimm o de Perrault, a los cuales se hace referencia de manera frecuente y única.

En el Oriente, las Mil y una noches presentan seres, lugares y situaciones que desbordan, y mucho, el imaginario occidental de los cuentos maravillosos. Un universo mezcla alegremente estratos y figuras de Sobrenaturaleza que proceden de diferentes civilizaciones y épocas. Se encuentran textos anteriores a las Mil y una noches que rozan lo maravilloso (véase el catálogo de la exposición L'Étrange 
et les merveilleux en terres d'Islam) y enciclopedias como Las maravillas de las cosas creadas y las curiosidades de las cosas existentes de Al Quazimi (1290, Bagdad). Estos textos tratan de personas extraordinarias, de poblaciones extrañas y de monstruos antropomorfos. Hay en ellos djinns o ángeles malos, cuyo origen se remonta al combate narrado en el Corán entre Dios e Iblis. Otros incluso como los Ghuls y los Djinn. En África se intenta incluso hoy recolectar numerosos cuentos antes de la muerte de los griots (véase Copans y Cousty). ${ }^{8}$ Los habitantes de las islas Mascareignes ofrecen su parte de cuentos, tanto malgaches como mauricianos (véase Longchamps y Contes de l'Ile Maurice).

Por otro lado, deidades de origen indio tomadas de los Avesta -los deaeva benefactores- son transformadas en diw, demonios de esencia espiritual, pero representados con una apariencia bestial: híbridos de hombre y de animal, de cuya condición poseen las garras, los pelos y los cuernos. Algunas figuras originales no tienen equivalencia en Occidente: el pájaro fabuloso del Simurg, tomado del imaginario iraní preislámico. Hay ahí, como decía poéticamente Paul Valéry, "d'étranges enfants que nos ancêtres faisaient, en s'accouplant dans les ténèbres, à toute énigme".

En otras palabras, los universos que los maravillosos proponen son innumerables, y todos remiten por algún camino a las relaciones de la Sobrenaturalaza y de la cultura. Esto es exacto para cada una de las diversas civilizaciones que se sitúan o se hallan en la edad pretécnica o preindustrial. Es decir, antes del siglo XVIII en Occidente $-\mathrm{y}$ en otras partes, antes del encuentro con el mundo occidental en el siglo XIX, como China o Japón, o antes de 1492 en las Américas. ${ }^{10}$

${ }^{8}$ Griot : en el África sudsahariana, cuentero ambulante al que se atribuye ocasionalmente poderes mágicos [N. del T.].

9 "Extraños hijos que nuestros ancestros concebían, acoplándose en las tinieblas, en el mayor misterio".

${ }^{10}$ Notemos que la dimensión de lo maravilloso no se agota con la llegada de lo "maravilloso científico" y de la ciencia ficción. Lo prueban en Occidente obras de imaginario puro preindustrial pero posteriores al siglo XVIII: Alice in Wonderland (1865), 


\section{Advenimiento de los textos "fantásticos" en Occidente}

La dimensión de lo maravilloso es, pues, muy antigua y universal. Por el contrario, los textos "con efectos de fantástico" son más recientes y tienen un origen determinado a la vez en lo histórico: su aparición puede datarse en el paisaje editorial entre fines del siglo XVIII y principios del XIX y en lo geográfico: nacen en esta época en Europa y los Estados Unidos.

La hipótesis más frecuentemente utilizada para explicar lo que aparece como un acontecimiento, y por ende como un total imprevisto, es establecer una relación con un cambio de paradigma social, simbólico y técnico en Occidente. La revolución inglesa de finales del siglo XVII conoció un primer atentado en la tripartición de Dumézil, ${ }^{11}$ que ofrece una descripción de las estructuras y las dinámicas sociales desde el neolítico: el trabajador, el guerrero (la nobleza) y el sacerdote. Fuera de la posesión de la tierra y de sus ganancias, no había salvación posible ni ningún poder, toda vez que éste era santificado por el clero. Primero la Revolución Inglesa, luego la de los futuros Estados Unidos y finalmente la Revolución Francesa modifican (ciertamente con lentitud) esas representaciones y esas realidades. La posesión de la tierra ya no basta para crear la riqueza y en consecuencia obtener el poder en el momento de la revolución industrial, que otorga un lugar a la figura del ingeniero, después a la del banquero, es decir, a la burguesía. La religión -y por tanto el hecho de apelar a la Sobrenaturaleza- no es ya la única

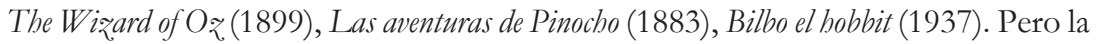
Sobrenaturaleza no es ya el resorte ni la guía en ellos. Un imaginario lúdico, que recuerda el presente en los escritos del Luciano de Samósata (siglo II d C) de las Historia verdadera, tomó el relevo y engendra encuentros fascinantes a base de metáforas complejas, de juegos de palabras o de una retórica diegética que se nutre de la búsqueda de sus propios efectos (véase Luciano).

11 "Il est survenu plus de transformations entre le Xviréme siècle et nous qu'entre les Indo-européens et le XvIIÍme siècle" ("han ocurrido más transformaciones entre el siglo XVIII y nosotros que entre los indoeuropeos y el siglo XVIII)" (Dumézil 189). 
clave del edificio social. Ya no basta con ser el "hijo de" (bidalgo) ni con desempeñar de la mejor manera el personaje que la sociedad aristocrática asigna a ese papel. Es el advenimiento de los modos de representación de la burguesía conquistadora lo que recupera la forma de la novela. Ésta muestra cómo un personaje se convierte en héroe construyendo su destino. Se convierte, en un medio que se democratiza, en un self made man. Asistimos entonces a una primera versión de la invención del individuo, con -lo cual corre parejo- la soledad angustiosa ante la pérdida del antiguo y tranquilizador medio de una Sobrenaturaleza y de sus encarnaciones sociales y simbólicas. ${ }^{12}$

Numerosos escritores -salidos de la nobleza como H. Walpole o M.G. Lewis- ponen entonces en escena, en las novelas "góticas", la melancolía de sus personajes ante las consecuencias de su pérdida de poder y la impotencia de sus deseos - prescindiendo de con cuánta fuerza-, como lo muestra el envilecimiento de Manfred en El castillo de Otranto. En Francia, Sade hiperboliza, por el contrario, el deseo de los poderes antiguos para deleitarse con ellos en una dimensión imaginaria. En todos los casos, el combate de los héroes de estos escritores se libra contra la Sobrenaturalaza, que según las obras aparecerá como vencedora en Walpole o como ídolo pisoteado y burlado en Sade. Para representar la impotencia de esos deseos, los autores recurren a lo irracional en forma de sueños, de imágenes oníricas, y ponen en escena todo el arsenal antiguo y derivado de los bordes de lo sobrenatural de los cuentos de miedo: con los fantasmas, los resucitados y pronto los vampiros. Estos monstruos y su violencia especulan con los efectos de terror ante esos "objetos",

\footnotetext{
${ }^{12}$ Una forma novelística nueva surgirá entonces con la "novela de aprendizaje" o Bildungsroman. Pero en el romanticismo la Sobrenaturaleza es diabólica, insiste en el miedo de perder la identidad. Esto se representará con la pérdida de la sombra por Peter Schlemihl, el héroe de Chamisso, o del reflejo por el personaje de Hoffmann que Peter encuentra en una taberna.
} 
como puede verse en $\underset{13}{E l}$ castillo de Otranto, El confesonario de los penitentes negros o El monje.

La revolución industrial, se ha dicho, implica, pues, en Occidente impensables cambios en las relaciones de las creencias, de las instituciones políticas y entre los individuos. Tiene por corolarios artísticos y filosóficos los movimientos de ideas y de sensibilidades nuevas que se han calificado como "romanticismos" y que se presentan en formas diversas, en Inglaterra y Alemania antes de penetrar en Francia y seguidamente en los países latinos. En Inglaterra después de los poemas de Young, luego de Byron y de Shelley, encontramos a Walter Scott con sus cuentos maravillosos, su encuentro con Washington Irving, y sus novelas históricas. En Alemania el romanticismo conoció diversas formas y contribuyó al nacimiento de un nacionalismo. Está vinculado en parte con pensadores como Herder, con Hegel en el despegue de la filosofía, con los hermanos Schlegel en la estética; o con los poetas, como Hölderlin o Novalis, y autores de colecciones de cuentos como los hermanos Grimm. Cuenta igualmente entre sus integrantes con autores de novelas cortas como L. Tieck, Achim von Arnim y E.T.A. Hoffmann. Todos enfrentan la pérdida de los viejos marcos simbólicos y afrontan la dificultad de dar forma a lo que aparece como lo irracional y no ya, salvo marginalmente, como lo sobrenatural. Lo cual implica un replanteo de las relaciones entre ese irracional vivido como encuentro impensable con lo "real", en tanto que lo sobrenatural y las instituciones relacionadas con ello tienden a no proponer más un marco de justificación suficiente. El registro de los romanticismos, y el sentimiento de lo fantástico que nace en la época, remiten al problema engendrado por la llegada de un impensable, de un irracional social y físico que no sirven ya de marco a un conjunto claro de símbolos.

${ }^{13}$ Horace Walpole, The Castle of Otranto (1764); Mathew George Lewis, The Monk (1796); Ann Radcliffe, The Italian or the confessional of the Black Penitents (1797). 
¿Cómo situarse ante lo que aparece entonces como irracional e impensable: la emergencia de nuevas formas de sociedad y de nuevos desafíos sociales? Ya no les es posible a los intelectuales, aristócratas o burgueses, continuar representando (o representándose) las viejas relaciones de la razón con la Sobrenaturaleza. Éstas se situaban dentro de una realidad simbólica, pero el paradigma conceptual y el aspecto emocional ligado a él resultan trastornados. Lo real nuevo, en esta perspectiva, aparece entonces como "incongruente", e impensable. La respuesta necesaria implica, para la captación de la nueva distribución y de la aporía, nuevas estrategias intelectuales, emocionales y narrativas, que engendrarán originales efectos de retórica. Éstos serán abordados por la creación de ficciones de tipo nuevo, dentro del romanticismo alemán, así como por los textos fantásticos.

Los románticos alemanes, lo mismo prosistas y poetas como Novalis que filósofos como Schlegel, tratarán de reencontrar una unidad y de dar una coherencia a lo real nuevo. Tratarán de captar el mundo por medio de la poesía y del género del Märchen. Para los románticos, la poesía aprehende lo real captándolo a la vez en su carácter fragmentario y su multiplicidad, y lo vuelve perceptible en forma de símbolo.

Paralelamente, los textos que instalan un "sentimiento de fantástico" -es decir, que ponen en escena la extrañeza nueva de las relaciones humanas en el universo que se construye- destacan la ansiedad, el espanto, o el terror que se deriva de esas nuevas e incomprensibles relaciones. Dichos textos nacen en esta época, en el interior del gran movimiento de los romanticismos, pero ofrecen una variante original de ellos.

Se apoyan en las paradojas e incongruencias que nutren el sentimiento de extrañeza ante el nuevo mundo. Sus autores construyen novelas cortas o novelas en las que la representación que ellos esbozan trata de dar forma a la irracionalidad aparente. Asumiendo a su manera el double bind enunciado por la Marquesa de Deffand acerca de los fantasmas: "No creo en ellos, pero les tengo miedo". 
Pero también confrontando la vida diurna cotidiana con el mundo del sueño, de los sueños, ${ }^{14}$ de las pesadillas y de los paraísos, para sacar de ellos motivos para sentir, como lo hará Charles Nodier a propósito del sueño, una fuente de la que brote sentido, con lo cual invierte las ideas habituales sobre la preeminencia de la razón: el espíritu - dice- se libera de las tinieblas de la vida exterior, el sueño de la razón encuentra ahí la fuente de los mitos y una autenticidad.

Esta relación entre el sueño y la creación -totalmente extraña al pensamiento clásico anterior- está también en el origen de la primera novela gótica de Horace Walpole y en el de la novela de horror ontológico que es Frankenstein, or the Modern Prometheus (1818), de Mary Shelley. Será uno de los temas de base de los textos fantásticos de Gautier, como "Arria Marcela" (1863). Tema que se vuelve a encontrar en Alemania con Gradiva, de Jensen (1903).

\section{Los textos fantásticos y la noción de "género"}

Estos textos diversos sólo serán, sin embargo, aproximados unos a otros y captados como pertenecientes a un "género" por una ironía de la Historia. Una traducción defectuosa del título de una compilación de Hoffmann donde "fantasía" se traslada como "fantástico" unida a un comentario de Walter Scott sobre el Fantastic mode que sería propio de la escritura de Hoffmann, iiy el género "fantástico" será inventado!!

Un género es a la vez una etiqueta y un medio; nace en un contexto histórico preciso, de manera imprevisible y responde a una expectativa vaga; luego se desarrolla según modalidades imprevisibles. Reflexionando, pues, sobre lo maravilloso en la novela, Walter Scott en 1828, después de haber presentado sus propuestas, toma como ejemplo que no debe seguirse los cuentos de Hoffmann,

${ }^{14}$ Del sueño, de los sueños: lo primero se refiere al estado opuesto a la vigilia (sommeil); lo segundo, a imágenes que pueden generarse durante ese estado (rêves) [N. del T.]. 
insistiendo en lo extravagante, lo incongruente, lo grotesco de sus obras. Éstas son traducidas al francés en 1829, con la parte crítica del artículo de Scott como prefacio, lo que suscita una polémica con numerosos críticos franceses, entre los que se hallaba J. J. Ampère. Éste, retomando las observaciones negativas de Scott, las resitúa en la dimensión de una originalidad total, y presenta a Hoffmann como el creador de una aproximación inédita y en fase con la nueva realidad. Los cuentos hoffmannianos se vuelven entonces un modelo, son imitados y acaban por ser percibidos como un "género" -teniendo en cuenta que Nodier en un artículo de 1830 titulado "De lo fantástico en literatura" parece haberle dado su unción. Estos textos producen en el lector "efectos fantásticos": ya manteniendo en y por parte del texto una ambigüedad del tipo de la que señalaba Madame du Deffand, quien no cree en fantasmas (aspecto racional) pero les tiene miedo (aspecto emocional, irracional); ya jugando con elementos de un terror que deja a los personajes sin voz, aterrados; ya confrontándolos con el terror; ya poniéndolos frente a un impensable que los deja estupefactos, como el narrador al final de la novela corta de Poe "Ligeia" (véase Bozzetto).

Los textos, numerosos y variados, que producen los efectos de fantástico son percibidos como pertenecientes a un "género". Responden a una expectativa que toma en cuenta lo irracional nuevo engendrado por las nuevas realidades sociosimbólicas. Pero eso no implica en absoluto una homogeneidad: los textos románticos de Gautier se derivan de ese género con el mismo derecho que las novelas de horror de Stephen King; The Turn of the Screw de H. James y sus refinamientos textuales coexisten con las novelas de Masterton, de una crudeza cercana a lo gore. El "género" fantástico no es, pues, un conjunto de textos organizados de manera coherente. Descansa en retóricas diversas que muestran la representación horrorizante del surgimiento, lento o rápido, de un impensable destinado a perturbar un universo presentado como estable, verosímil y cotidiano. ${ }^{15}$

${ }^{15}$ Una vez creado el género, éste evoluciona; lo que explica que hoy los imaginarios y los terrores de las novelas de S. King, C. Barker, G. Masterton o S. Bussolo, por 
Estos textos mimetizan el testimonio de una apertura a lo innombrable, y el testimonio resulta de una angustia ante realidades de-simbolizadas, que remiten a "la proximidad de lo real" de la que habla Clément Rosset. Son textos que apelan a una de las estrategias literarias que confrontan al lector con lo impensable por medio del uso de una retórica que intenta convertir en imagen "lo imposible de decir que, sin embargo, está ahî”. El modelo servirá en el caso de otros choques de civilizaciones, en los escritos de autores de lo que actualmente se denomina las culturas emergentes, y que han desembocado en los textos de real maravilloso.

\section{Fantástico y real maravilloso}

A veces se presenta como derivados del mismo género fantástico ciertos textos de autores como Julio Cortázar o Bioy Casares -o incluso Felisberto Hernández. Y es comprensible puesto que el mismo Cortázar utiliza la noción de "fantástico" en sus reflexiones, en sus prefacios (véase Terramorsi). Sin embargo, es difícil considerar "Carta a una señorita en París" como un relato que produciría los mismos "efectos de fantástico" que "Casa tomada" o "Las armas secretas" -textos que remiten a una concepción occidental del texto fantástico.

"Carta a una señorita en París" está mucho más cerca de relatos como "La casa inundada" o "El cocodrilo", de Hernández. Es decir, de textos que, en forma de un grotesco o de un barroco original, presentan una especie de delirio que desemboca en una aparente alegoría de la inmensa riqueza de los posibles, sin significación precisa, pero con una fuerte carga emocional. Lo mismo ocurre con los relatos de juventud de Gabriel García Márquez Ojos de perro azul. ${ }^{16}$

ejemplo, puedan considerarse parte de él, lejos de la ambigüedad inicial, pero siempre confrontados a un "imposible y, sin embargo, está ahí”.

${ }^{16}$ No obstante, la dimensión fantástica puede continuar leyéndose en ciertos textos de Carlos Fuentes, como Aura (1962). 
También en ellos se presentan como evidentes hechos impensables y se deja sin otra significación que una especie de estupefacción del lector, dando la impresión de asumir de ese modo la realidad en toda su plenitud. ${ }^{17}$

Un autor haitiano, René Depestre, muestra un ejemplo a la vez próximo y diferente de las literaturas de lo real maravilloso. ${ }^{18}$ Para él, existe quizá en esa encrucijada de culturas, más que en cualquier otro lugar, una "métaphysique des êtres et des lieux qui obéit à la logique étrange du rêve" (Depestre, Hadriana 148). ${ }^{19}$ Además se notará que esos textos presentan ese maravilloso y las representaciones realistas habituales "combinándo[las] de manera armoniosa, sin volver antagónicas ambas lógicas” (Chiampi 32). Se notará que lo mismo es válido para el aspecto religioso: los códigos y las imágenes de la religión de los Blancos han sido reinterpretados dentro del marco de una hibridación con las tradiciones africanas. Así nacieron en Haití las prácticas del vudú, que propone una dimensión original, o desviada y que conduce al delirio o a la locura, de la relación con la Sobrenaturaleza (Véanse Phillipe y Laenec).

El paso de un tipo de modelo cultural a otro implica, en el plano simbólico como en el literario, la invención de textos. Éstos, al principio marginales, se hibridan para crear seguidamente aproximaciones

${ }^{17}$ Se podría asociar esos efectos a los producidos en textos de Franz Kafka como "La colonia penitenciaria" o "La metamorfosis", o en los textos del italiano Tomaso Landofi.

18 "La notion de réel merveilleux américain a pris des directions et des colorations diverses dans les œuvres d'Alejo Carpentier, Jorge Amado, Rulfo, Asturias, Cortazar [...] Dans Cent ans de solitude le réel merveilleux américain passe par le point de sa trajectoire le plus élevé des horizons écologiques, historiques, érotiques, religieux, ludiques, individuels et collectifs des Amériques" "La noción de real maravilloso americano ha tomado direcciones y coloraciones diversas en las obras de Alejo Carpentier, Jorge Amado, Rulfo, Asturias, Cortázar [...] En Cien años de soledad lo real maravilloso americano alcanza el punto más elevado de una trayectoria en lo que respecta a los horizontes ecológicos, históricos, eróticos, religiosos, lúdicos, individuales y colectivos de las Américas.”) (Depestre, Le Métier 113).

19 "Metafísica de los seres y de los lugares que obedece a la lógica extraña del sueño." 
literarias nuevas dentro del marco de una ruptura asumida con las formas viejas "osificadas", e impuestas por una cultura dominante. Estos textos son percibidos luego como pertenecientes a un "género". Se desembarazan, así, de un adoctrinamiento simbólico presentado como derivado "de la naturaleza de las cosas" o de la "tradición" cultural legitimada en otra parte. ${ }^{20}$

Del mismo modo que el sentimiento trágico de la vida encontró una figuración explícita con las tragedias griegas contemporáneas a la consolidación de las ciudades griegas, el sentimiento de lo fantástico tomó forma en Occidente con la invención de un género después de la primera revolución industrial. Los textos actuales derivados de la world fiction o presentados bajo otros sellos del mismo tipo han de situarse dentro de los trastornos que sufre nuestro planeta como parte de su "globalización" (ver Astic). En cada ocasión, la creación de un género ha sido la resultante de un trastorno, de una ruptura drástica en un tipo de sociedad.

Para lo fantástico occidental, es el impacto de la naciente civilización industrial sobre un mundo salido del neolítico. A los autores latinoamericanos y caribeños (entre otros), la "descolonización" de los espíritus los induce a inventar "una imaginería en la cual un pueblo envuelve su experiencia, refleja su concepción del mundo y de la vida". Y cuyo ejemplo más conocido es lo real maravilloso.

\section{Lo real maravilloso}

Para autores caribeños, uruguayos o colombianos de los años 19451955, se impone la conciencia de la necesidad de una ruptura con

${ }^{20}$ Un problema que se ha comprendido mal es el del "occidentocentrismo", tanto literario como político y que corresponde a un período histórico que se ha vuelto obsoleto en algunos lugares, pero cuyos marcos de pensamiento "osificados" subsisten. Ellos impiden por momentos tomar en cuenta la originalidad de otras culturas, pues aun cuando la perciban, la miden de acuerdo con las reglas occidentales. Como sugiere S. Rushdie, se necesita un descentramiento de la mirada para permitir una variación de las perspectivas y un examen de la realidad. 
las formas narrativas y el imaginario europeos -hasta entonces vividos como modelos canónicos. Y tanto Alejo Carpentier como René Depestre se liberan de ellas. ${ }^{21}$ Ocurre entonces el redescubrimiento de un imaginario precolonial, que permite inventar nuevos mestizajes. ${ }^{22}$ También ciertos relatos de Julio Cortázar recurren a una cultura original proveniente de mitologías precolombinas. ${ }^{23}$ Es el caso de "Axolotl" y de "La noche boca arriba", donde se apela a imágenes que remiten al mundo de dioses como Xólotl y a metamorfosis, o a la Guerra Florida emprendida por los aztecas para nutrir al sol y por ende a la vida en la Tierra. Esta presencia subterránea y casi alusiva de mitos culturales autóctonos es, sin embargo, necesaria para captar la profundidad de las imágenes representadas y la densidad emocional que ellas suscitan. En Japón, después de los textos de Agutagawa y de Tanizaki, Koji Suzuki renueva el tema de los fantasmas en los mundos urbanizados contemporáneos, con una puesta en abismo de los media mismos como apertura a los monstruos del pasado en películas como Ring o Dark Waters. En India puede mencionarse a O.V. Vijayan, quien ha publicado Les légendes de Khasak.

Y podrían encontrarse numerosos ejemplos en otras culturas emergentes, donde se impone la solución de la ruptura con los

${ }^{21}$ Un problema que se ha comprendido mal es el del "occidentocentrismo", tanto literario como político y que corresponde a un período histórico que se ha vuelto obsoleto en algunos lugares, pero cuyos marcos de pensamiento "osificados" subsisten. Ellos impiden por momentos tomar en cuenta la originalidad de otras culturas, pues aun cuando la perciban, la miden de acuerdo con las reglas occidentales. Como sugiere S. Rushdie, se necesita un descentramiento de la mirada para permitir una variación de las perspectivas y un examen de la realidad.

22 "En América Latina se nos ha enseñado que somos españoles. Es cierto, en parte, porque el elemento español forma parte de nuestra personalidad cultural. Pero en aquel viaje a Angola descubrí que también éramos africanos. O mejor, que éramos mestizos. Nuestra cultura es mestiza, se enriquecieron con diversos aportes [...] Se mezcló la imaginación desbordada de los esclavos negros africanos con la de los nativos precolombinos y luego con la fantasía de los andaluces. Nunca, hasta entonces, había tenido conciencia de ello" (García Márquez 68).

23 "En la obra de Carpentier el concepto de "real maravilloso" se resuelve narrativamente en las intersecciones constantes del mito y de la historia”(Fell 235). 
modelos occidentales seguida de la elaboración de un texto mestizo donde se mezclan los sustratos antiguos, las referencias a la modernidad de la novela, al aspecto alegórico y a lo sobrenatural, no ausente del todo. En Hadriana dans tous mes rêves, Hadriana, y todos sus sueños, son también Haití. Hadriana es una joven que, al ir a la ceremonia religiosa de su matrimonio, es raptada y convertida en zombi. Presuntamente muerta y desaparecida en 1938, reaparece efectivamente ante el narrador en 1977, sin dar razones en verdad de si no vivió en otro lugar, en Jamaica. En esto puede leerse, de una manera a la vez metafórica y tendiente a dar una visión maravillosa de la realidad, una representación de Haití, también convertido en zombi después de haber tomado el veneno de la presencia colonizadora de los Blancos, que cortó "la filiación natural entre lo Real y lo maravilloso". Lo real maravilloso se presenta entonces como "la négation poétique et romanesque des circonstances historiques de la conquête coloniale"24 (Depestre, Le Métier 112). Los textos proponen una representación dinámica entre el "realismo" occidental del siglo xix, que se muestra inapropiado, y un maravilloso derivado de una aproximación original a la Sobrena-turaleza y a lo sagrado. Depestre lo representa metafóricamente como la imagen de "fragiles compromis entre rituels catholiques et vaudou, frères ennemis qui se disputèrent le corps et l'âme de la jeune femme" 25 (Le Métier 53).

En lo real maravilloso, mitos y leyendas y cuanto remite a la Sobrenaturaleza no aparece como maravilloso, sino como la presentificación de un realismo total que engloba lo que se halla separado en el "realismo occidental". Se trata de una nueva forma de ver las cosas que, como en Rosset pero por otras razones, glorifica la maravilla reencontrada del estar-en-el mundo. (Véase Rosset)

\footnotetext{
24 “La negación poética y novelística de las circunstancias históricas de la conquista colonial."

25 "Frágiles compromisos entre rituales católicos y vudú, hermanos enemigos que se disputaron el cuerpo y el alma de la joven."
} 
En otras palabras, los textos de lo real maravilloso son una manera de traducir la realidad vivida de un período de la civilización sudamericana. Período en el que ésta se encuentra en la imposibilidad de percibir el mundo por medio de modelos occidentales histórica y geográficamente determinados, concebidos para otros universos, y que se presentaban como universalizables. Es en este sentido que el método de los escritores de lo real maravilloso puede servir de ejemplo, si no de modelo, para los escritores de las "literaturas emergentes" (Magdelaine-Andrianjafitrimo 93, nota 1).

Los textos que se relacionan directamente o no con lo real maravilloso no manifiestan un rechazo a esas viejas pretensiones culturales; son una respuesta adaptada a la imposibilidad de seguirlas, tratando a su manera de dar sentido a esta imposibilidad misma. Fue una posición similar, en una época diferente, la que hizo necesario el advenimiento del "género" fantástico en Occidente y permite hoy agrupar - equivocadamente o con razón- a numerosos autores de culturas emergentes relacionados con el "¿género?" de lo real maravilloso.

\section{Mitología, literatura e ideología}

Toda cultura está inmersa en un universo simbólico que la constituye y que ella utiliza a su manera. Se apoya en la presencia subterránea pero pregnante de mitos, y de referencias, aun cuando sean sólo metafóricas, a lo sobrenatural. Y esto, aun cuando ella no tiene verdaderamente conciencia de eso. Los mitos de hoy no son ya grandes relatos que se reciten, sino realidades que se ocultan, como las antiguas deidades, para obrar de modo más efectivo. Es así como podemos ver nuestros comportamientos modelados por una multitud de señales, venidas de un Olimpo invisible, que incitan a comprar, a consumir, a vestirse de una forma o de otra, a apreciar tal o cual cosa, a amarse de tal o cual modo, a pensar, a escoger, en nombre de la norma, o de la democracia, o del placer codificado, etc. Esas señales múltiples que la publicidad, los "maestros pensadores", las "autoridades", las vedettes, las stars retransmiten, son la 
cara visible de una ideología de múltiples máscaras, que es la de la "mercantilización" del mundo y de los deseos humanos.

Ella es la consecuencia de la "occidentalización" de las culturas, en nombre de la simple rentabilidad económica a corto plazo a la que ella reduce todo. Los textos con efectos fantásticos anteriores eran actas de un estado de hecho ante el que la razón se bloquea, y esto sigue siendo cierto incluso en los textos de horror de Stephen King. Las obras de lo real maravilloso me parecen más tónicas, más proclives a impugnar los esquemas y valores que la "occidentalización" propone, y que la televisión y los sitios com imponen como "naturales" -iiy por ende "universales"!!-, puestos en el centro de la autoproclamada "civilización occidental".

Los textos deudores de los instrumentos nuevos creados por lo real maravilloso se sitúan en la periferia de ese universo cerrado; muestran que otras formas de "vivir juntos" son posibles, que la alegría de vivir ante el simple hecho de existir es un valor primordial. Muestran que pueden nacer y mestizarse mitos nuevos para provocar producciones de sentido. Muestran también que los mitos viejos no han perdido su fuerza; que pueden todavía y siempre nutrir los imaginarios y aportar esperanza en la lucha difícil contra la uniformidad y "el desencanto del mundo".

Evidencian que las culturas emergentes no están condenadas a repetir los errores de las culturas más viejas. Su literatura sirve también, por su sola presencia, para devolver al universo el sabor de las primeras veces.

\section{Obras citadas}

Astic, Guy. "'Le roman international' européen. Trois figures d'un renouveau romanesque: Günter Grass, Milan Kundera, Salman Rushdie." Tesis doctoral. Université de Aix en Provence, 2002 Bottéro, Jean. La plus vieille religion. En Mésopotamie. Paris: Folio Histoire, 1998.

Bozzetto, Roger. "La recherche de l'émerveillement et de la sidération." Europe 868-869 (agosto-sept 2001): 138-147. 
Catalogue de l'exposition L'Etrange et les merveilleux en terres d'Islam, avriljuillet 2001. Paris: Bibliothèque Nationale, 2001.

Chiampi, Irleman. O realismo maravilloso. Sao Paulo: Perspectiva,1980.

Contes de l'Ile Maurice. En Contes du monde entier. Paris: CLE International, 1981

Copans, Jean y Philippe Cousty. Contes wolof du Baol (10-18). Paris: Union Générale d'Éditions, 1976

Demeretz, Alain. "Petite histoire desdefinitions du mythe :le mythe,unconcept ou un nom." En Mythe et création. Ed. Pierre Cazier (Travaux et recherches). Lille: Presse Universitaire de Lille, 1984. 15-32.

Depestre, René. Hadriana dans tous mes rêves [1988]. Paris: Folio, 2000. . Le Métier à métisser. Paris Stock, 1998.

Dumézil, Georges. Entretiens avec Didier Eribon. (Col. Folio essais). Paris: Gallimard, 1987.

Fell, Claude. "Mythification et démystification dans La Harpe de l'Ombre." En Alejo Carpentier et son cuvre. Coord. Olver Gilberto de León. Marseille: Revue SUD, 1982.

"La fille du roi dragon." En: Légendes de dragons. Récits chinois. 2a. ed. (Collection Panda). Beijing: Éditions de littérature chinoise, 1993.

García Márquez, Gabriel. El Olor de la guayaba. Bogotá: Editorial Oveja Negra, 1982.

"La jeune fille en robe verte." En: Pu Song Ling. Contes fantastiques du pavillon des loisirs. Beijing: Éditions en langues étrangères, 1986.

Jolles, André. Formes simples. Paris: Seuil, 1970.

Laenec, Hurben. Les mystères du vaudou. (Col. Découvertes). Paris: Gallimard, 2003

Levi-Strauss, Claude. Anthropologie structurale. Paris: Plon. 1958.

Longchamps, Jeanne de. Contes malgaches. Commentaires de Paul Delarue. Paris: Ed Erasme, 1955.

Lovecraft, Howard Philip. Epouvante et surnaturel en Littérature. Paris:

Union Generale D’Éditions, 1975.

Lucien de Samosate. Histoires V raies. Paris: Livre de poche, 2003. 
Magdelaine-Andrianjafitrimo, Valérie. "Ethnotexte et intertextualité: la mise en scène des représentations culturelles dans les romans 'ethnographiques"." En Contes et romans. Univers Creoles 4. Eds. Valérie Magdelaine-Andrianjafitrimo y Carpanin Marimoutou. Paris: Anthropos, 2004.

Magdelaine-Andrianjafitrimo, Valérie, Jean-Claude Carpanin Marimoutou et Bernard Terramorsi Démons et merveilles, Le surnaturel dans l'Océan Indien. [Saint-Denis]: Université de La Réunion, 2005.

Nodier, Charles. "Du fantastique en littérature." En: Contes fantastiques. Nouv éd. Paris: G. Charpentier éditeur, 1982. 5-30. Philippe, Bernard. Rêve et littérature romanesque en Haïti. Paris: L'Harmattan, 2004.

Rosset, Clément. Le monde et ses remèdes (1964). Paris: PUF, 2000. Schaufelberger, Gilles y Guy Vincent. Introduction a Le Mahabharata. I. "La genèse du monde." Trad. y notas de Laval (Quebec): Presses de l’Université de Laval, 2004. 93-96.

Scott, Walter. "On the Supernatural in Fictitious Compositions; and Particularly on the Works of ETA Hoffmann." Foreign Quaterly Review 1 (1827): 60-98.

Szyzlo, Fernando de. "La Bouche d'ombre et le noir arc en ciel." En Nouveau mondes, autres mondes. Surréalisme et Amériques. Coord, Jacqueline Chénieux-Gendron. (Coll. "Pleine marge" 5) Paris: Lachenal et Richter, 1995.

“Teng Mu ivre visite le parc des Paysages Assemblés." En: En mouchant la chandelle. Nouvelles chinoises des Ming. (Col. L'imaginaire). Paris: Gallimard, 1986.

Terramorsi, Bernard. Le fantastique dans les nouvelles de Julio Cortazar. Paris: L'Harmattan, 1994.

VV. AA. Mythes et mythologie dans l'antiquité gréco-romaine. Número monográfico de Europe 904-905 (julio-agosto de 2004). 